\title{
INVESTIGATING THE EFFECT OF DRAMA AS TEACHING TECHNIQUE ON GRADE EIGHT STUDENTS' VOCABULARY ACQUISITION
}

\author{
Deddy Suezdi ${ }^{1}$, Denada ${ }^{2}$
}

\author{
English Education Department, Faculty of Teaching and Educational Sciences, Universitas \\ Islam As-Syafi'iyah Jakarta
}

\begin{abstract}
This research entitled "Investigating The Effect of Drama as Teaching Technique on Grade Eight Students' Vocabulary Acquisition at MTs Assyairiyah Attahiriyah Jakarta" principally aims to investigate whether or not drama technique significantly affects students' vocabulary acquisition. The research samples were taken using cluster random sampling, with the total number of samples being 60 students. The location of this research was MTs Assyairiyah Attahiriyah Jakarta. The research methodology adopted was quasi-experiment method, with the research design being post test only control group design. To collect the data, the students were given the objective test, numbering 30 items. The research data were analyzed descriptively and inferentially. The findings indicated that there was significant difference of post-test score between the students who received drama technique and students who did not receive drama technique. It can be seen from the data analysis using ANOVA that showed $F_{\text {observed }}\left(90.988\right.$ ) is higher than the critical value of $F_{\text {table }}$ (at the significant level of 0.05 and $\mathrm{df}=1 / 84$ ), namely 3.96 . it means that drama technique has significant effect on students' vocabulary acquisition.
\end{abstract}

The key words : Drama Technique, Vocabulary, Vocabulary Acquisition

\section{Introduction}

Today English is being learnt by billion people because a working knowledge of English is required in certain fields, proffessions, and occupatios, English is studied and spoken by over a billion people around the world to at least a basic level. English has also been a very important subject in Indonesian education, because the government has proclaimed that it is one of the compulsory subjects which become the parts of national exam. 
As response to the strategic and important position of English in national, regional, and international arena, our government applies school basic curriculum (KTSP) to improve previous curriculum in terms of the aim that wants to be realized. As regard the 2004 KTSP (kurikulum tingkat satuan pendidikan), the government decided to establish English as the first foreign language to be taught in Indonesia's educational institutions beginning from Junior high school to University. The government policy was put into the curriculum to develop students' ability, the teacher determine on their own materials including four basic of language skills: Listening, speaking, reading, and writing.

The expectancy of this curriculum seems too high despite the fact that the student's ability in English remains low from year to year. This is evidenced from the English score in national exam of Junior high school students in 2016 decreased 2,84 points and from the result of the national exam, as many as $41,92 \%$ of students got mean under 55 or has not reached the standard score, there is only $4,04 \%$ of students who got the score of over $4,04 \%$ (Anies Baswedan, May 11, 2016).

There are various factors responsible for the students' low achievement in English. Steven (2001) maintain that linguistic factors such as syntax and vocabulary, words spelling and pronounciation are accountable for students' poor achievement in English.

As stated above, vocabulary is one of the linguistic components which can bring about low achievement in English. Vocabulary play an important role because it carries contents to convey ideas or information. Regarding this issue, some researches give emphasis on the importance of vocabulary. Wallace (1982) admit that; "Although people have a good knowledge of grammar, for example, they are not able to communicate in English yet. Whereas, if they have the vocabulary they need it is usually possible to communicate" (p.82). However, our students' vocabulary mastery is still inadequate. This opinion was forwared by Murcia (1997) who says that "some students claim that their primary problem in 
acquiring English is vocabulary. As a result, it is not surprising that students' English vocabulary is generally far from being statisfactory." (p.23).

To overcome the problem, a teacher should be able to find out ways and appropriate solutions to improving the teaching-learning process, they should know how to improve the students' interest and student's achievement in learning vocabulary. Teachers should be able to develop any kind of material so that learning vocabulary will not become such boring and monotonous thing.

Based on the problem above, this research was conducted to investigate whether or not drama technique can overcome students' difficulties in acquiring the vocabulary. According to Sharim-Paz as cited in Warta (2008, p.3) drama activity can make the study and practice of English interesting, enjoyable and dynamic. She believes that students gain much encouragement from the dialogues and that enjoyment motivates them to develop their language skill. What is more, the drama itself, she claims, provides the teacher with a set of skills that will be usefull to him/her as a teacher of English in the future.

Researches conducted by Khalifa and Dahami (2015) and Demircioğlu (2010) shows that the application of Drama in English language classroom improves the vocabulary learning and greatly assisted language development. The research findings also revealed that drama as a teaching technique promotes long-term retention of vocabulary.

Based on the explanation above, This research aims to find out whether the use of drama significantly improves Indonesian students' vocabulary acquisition especially at MTs assyairiyah attahiriyah Jakarta. To examine the effect of drama on grade eight students' vocabulary acquisition at MTs Assyairiyah Attahiriyah Jakarta, the research question is formulated as follows : "Is there any significant effect of drama on grade eight students" vocabulary acquisition at MTs Assyairiyah Attahiriyah Jakarta?" 


\section{Method}

\section{Hypotheses}

To find out whether or not there is significant effect of drama on grade eight students' vocabulary acquisition, the hypotheses are formulated as follows;

\section{Null Hypothesis $\left(\mathrm{H}_{0}\right)$}

There is no significant effect of using Drama Technique on grade eight students' vocabulary acquisition at MTs Assyairiyah Attahiriyah Jakarta.

\section{Alternative Hypothesis $\left(\mathrm{H}_{\mathbf{a}}\right)$}

There is a significant effect of using Drama Technique on grade eight students' vocabulary acquisition at MTs Assyairiyah Attahiriyah Jakarta.

\section{Research Design}

In this research, the researcher used a Quasi Experimental method, in which the treatment condition did not allow a strict control. This design of this research was post-test only control group design. The first group namely as experimental that received drama technique and other group namely as control group that did not receive drama technique. Both groups were given post test.

\section{Participants}

The population of this research is grade eight students at MTs Assyairiyah Attahiriyah Jakarta in academic year 2016/2017 at the second semester, consisiting of 90 students. To determine the sample of this research, the writer used Cluster RandomSampling. The number of students that participated in this research is about 60 students devided into two classes consisting each of 30 students in VIII.A as experiment class and 30 students in VIII.B as control class. 


\section{Variables and Measures}

In this research, independent variable is Drama Technique. Dependent variable in this research is Vocabulary Acquisition. To measure students' vocabulary acquisition, the writer took score from indicators of vocabulary, as follows;

1. The students are able to give the definition of the given word.

2. The students are able to identify the similar word (synonym).

3. The students are able to identify the opposite of the given word (antonym).

4. The students are able to fill in the blank the correct words.

5. The students are able to give Indonesian equivalence of the given English word.

\section{Validity and Reliability}

The indicators of vocabulary were developed to be instrument. The instrument was objective test with 50 items. Those items were analyzed its validity, reliability, difficulty index and discrimination power to obtain good instrument using Microsoft Excel 2007. After the items have been analyzed, the good items that valid, reliable, statisfactory and medium were chosen to obtain good data. The question items were left 31 numbers. But it was only used 30 good question items to simplify the data analysis.

\section{Procedure}

Procedures of the research are:

1. Planning

The planning phase involves : Preparing and arranging the research design to get the research data. Before conducting the research, the writer formulates the hypothesis based on some related theories and design teaching plan using drama technique in teaching vocabulary. 
2. Data Collecting

The data were collected by giving post test to the students in experiment class and control class.

3. Data Analysis

The data collected from the sample classes were analyzed by using ANOVA after the prerequisite analysis of normallity and homogeneity have been fulfilled.

4. Reporting

The research finding is reported and written based on the formal frame of writing.

\section{Result}

This research data were analyzed descriptively and inferentially. The descriptive statistic can be seen on the following table.

Table 1 : Descriptive Statistics

\begin{tabular}{|c|c|c|c|}
\hline \multicolumn{4}{|c|}{ Statistics } \\
\hline N & $\begin{array}{c}\text { CLASS } \\
\text { EXPERIMENT }\end{array}$ & $\begin{array}{c}\text { CLASS } \\
\text { CONTROL }\end{array}$ \\
\hline & Valid & $\mathbf{3 0}$ & $\mathbf{3 0}$ \\
\hline Mean & Mising & $\mathbf{0}$ & $\mathbf{0}$ \\
\hline $\begin{array}{c}\text { Std. } \text { Error of } \\
\text { Mean }\end{array}$ & & $\mathbf{7 0 , 8 3}$ & $\mathbf{5 3 , 3 7}$ \\
\hline Median & & $\mathbf{1 , 0 8 8}$ & $\mathbf{1 , 4 7 3}$ \\
\hline Mode & & $\mathbf{7 1 , 5 0}$ & $\mathbf{5 4 , 5 0}$ \\
\hline Std. Deviation & & $\mathbf{7 3}$ & $\mathbf{5 3}$ \\
\hline Variance & & $\mathbf{5 , 9 6 0}$ & $\mathbf{8 , 0 6 6}$ \\
\hline Skewness & & $\mathbf{3 5 , 5 2 3}$ & $\mathbf{6 5 , 0 6 8}$ \\
\hline $\begin{array}{c}\text { Std. } \text { Error of } \\
\text { Skewness }\end{array}$ & & $\mathbf{- 0 , 0 9 8}$ & $\mathbf{- 0 , 7 6 7}$ \\
\hline Kurtois & & $\mathbf{0 , 4 2 7}$ & $\mathbf{0 , 4 2 7}$ \\
\hline $\begin{array}{c}\text { Std. } \text { Error } \text { of } \\
\text { Kurtois }\end{array}$ & & $\mathbf{0 , 6 8 9}$ & $\mathbf{- 0 . 1 9 4}$ \\
\hline Range & & $\mathbf{0 , 8 3 3}$ & $\mathbf{0 , 8 3 3}$ \\
\hline Minimum & & $\mathbf{2 7}$ & $\mathbf{2 7}$ \\
\hline Maximum & & $\mathbf{5 6}$ & $\mathbf{3 6}$ \\
\hline Sum & & $\mathbf{2 1 2 5}$ & $\mathbf{6 3}$ \\
\hline
\end{tabular}


From the table above, Mean (Average Score) of Experiment Class was 70,83 and Control Class was 53,37. In experiment class, the maximum score was 83 and the minimum score was 56 while in control class, the maximum score was only 63 and the minimum score was 36. It indicated that students who received drama technique was higher than students who did not receive drama technique.

After the data were analyzed descriptively, the data were analyzed inferentially using One-Way ANOVA. The data were tested its normality (Kolmogrov Smirnov) and its homogeneity (Levene) as pre-requisite data analysis. The result of data analysis is presented as follows:

Table 2 : ANOVA

\begin{tabular}{|c|c|c|c|c|c|}
\hline & $\begin{array}{c}\text { Sum of } \\
\text { Squares }\end{array}$ & Df & Mean Square & F & Sig. \\
\hline $\begin{array}{c}\text { Between } \\
\text { Groups }\end{array}$ & 4576.267 & 1 & 4576.267 & 90.988 & 0.000 \\
Within Groups & 2917.133 & 58 & 50.295 & & \\
Total & 7493.400 & 59 & & & \\
\hline
\end{tabular}

The calculation showed that significant value is 0.000 . the significant value $0.000<$ 0.05, so $\mathrm{H}_{\mathrm{a}}$ was accepted and $\mathrm{H}_{\mathrm{o}}$ was rejected. Fobserved also can be used to find out whether or not there is an effect of variable $\mathrm{X}$ on $\mathrm{Y}$ through comparing with $\mathrm{F}_{\text {table. }}$. Degree of freedom was used to find out $F_{\text {table, }}$ (df) $(1,84)=3.96$. the result showed that $F_{\text {observed }}(90.988)>F_{\text {table }}$ (3.96). it can be concluded that there is significant effect of variable X (Drama) on variable Y (Vocabulary Acquisition). 


\section{Discussion}

The mean differences between the experimental group and the control group were computed to find out whether or not the differences were suffIcient to produce significant effect of one variable on the other.

From the result of post test, the experimental group gained the mean (average score) 70.83 while the control group gained the mean 53.37. To find out whether the differences in the two means above are significant enough to reject the H0, The writer adopted ANOVA statistics. Based on the result of analysis using ANOVA (SIG. $<0,05)$, The research rejected $\mathrm{H} 0$ and accept Ha, meaning that the differences in the mean of the experimental group and that of the control group were significant to conclude that there was significant effect of drama on grade eight students' vocabulary acquisition at MTs Assyairiyah Attahiriyah Jakarta in the Academic Year 2016/2017.

The research conducted by the writer at MTs Assyairiyah Attahiriyah was founded on the theories and assumption advanced by Sharim-Paz, which disclose that drama technique was effective for the teaching of vocabulary. To prove this empirically, the writer carried out the research with the number of samples being 60 students. The research revealed that drama techique exerted effect on vocabulary (Sig. .000 < 0.05 and Fobserved $90.988>$ Ftable 3.960). therefore, in compliance with the research findings describe above, the writer's research has proved the truth of the assumptions and has empirically verified the researches conducted by Kheirabadi (2013), Khalifa \& Dahami(2015) and Demircioğlu (2010) which proved the effect of drama on vocabulary.

The effect of drama in the research conducted by the writer at MTs Assyairiyah Attahiriyah Jakarta was caused by the better performance in the post test of vocabulary ability of the experimental group treated with drama technique compared to that of the control group given conventional method. 
The use of drama made the vocabulary and learning activity more effective. The students of experimental group who were taught by using drama technique looked more attracted and active during the treatment given by the writer than those in the control group which were taught by conventional method. The proof of the effectiveness of drama was evidenced in the result of their post test which was higher than their the control group. Finally, drama makes the students in the experimental class more motivated in learning and found easier to grasp the lesson. The use of drama as a technique in teaching and learning of vocabulary was effective for grade eight students of MTs Assyairiyah Attahiriyah Jakarta in the academic year 2016/2017.

\section{Conclusion}

This study can eventually concluded that there was significant effect of drama on grade eight students' vocabulary acquisition at MTs Assyairiyah Attahiriyah Jakarta in the academic year 2016/2017. This conclusion is based on the rejection of Ho and acceptance of $\mathrm{H}_{\mathrm{A}}$. The acceptance of $\mathrm{H}_{\mathrm{A}}$ is due to the fact that Significance value (Sig.) is lower than Alpha 0.05, and $\mathrm{F}_{\text {observed }}$ is higher than $\mathrm{F}_{\text {table. }}$

The effect of drama is shown by the better scores obtained by the experimental class treated with this technique in contrast to the lower scores obtained by the control class treated with conventional method. 


\section{REFERENCES}

Celce-Murcia. M. (2001). Teaching English as a Second or Foreign Language (3rd ed). USA: Heinle\&Heinle.

Demircioğlu ${ }^{a}$, Şerife. (2010).Teaching English Vocabulary to Young Learners Via Drama, Elsevier Ltd.

Khalifa, E.M \& Dahami, Y.S. (2015). Strengthening EFL Students' Vocabulary Through Learning Drama. International Journal of English Language, Literature and Translation Studies.

Kheirabadi, M.D\& Golchin, V.F. (2013).The Effect of Reading Short Drama on the Development of Vocabulary Skill of Iranian Advanced EFL Learners of English. International Journal of English Language Education.

M.S, IK. Warta. (2008) Drama and Language Learning: First Edition.Mataram: Sadampaty Aksara.

Sharim-Paz, S. (1976). Using Drama in Teacher Training. English Teaching Forum. Vol.4 No.1 1976: p.5-7.

Wallace, M. J. 1998. Material Developement Language Teaching. Cambridge: Cambridge University Press.

http://m.antaranews.com/berita/566651/penurunan-nilai-un-smp-di-semua-mata-pelajaran 